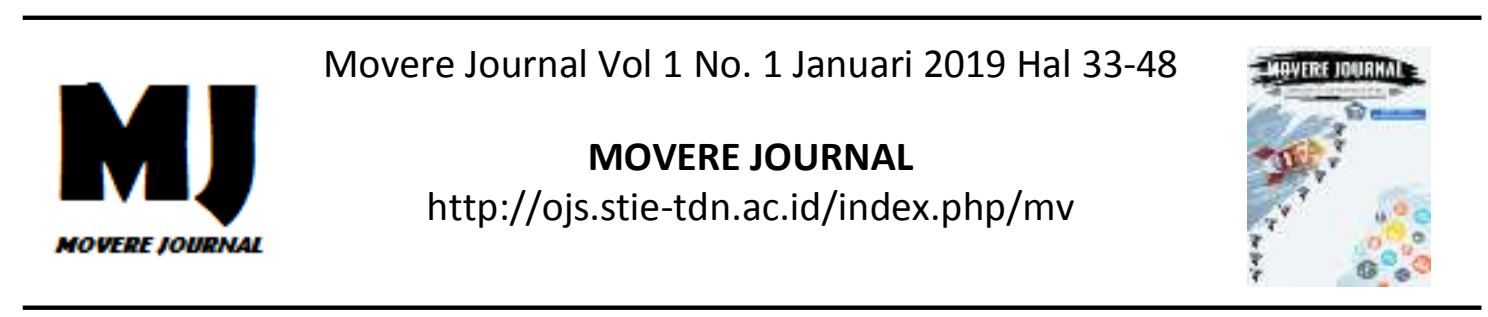

\title{
PENGARUH TINGKAT PENDIDIKAN DAN PENGALAMAN KERJA TERHADAP KINERJA GURU SEKOLAH MENENGAH PERTAMA NEGERI 3 BABA KECAMATAN CENDANA KABUPATEN ENREKANG
}

\author{
Muhammad Nadhar dan Abd. Azis \\ Universitas Islam Makassar
}

\begin{abstract}
Abstrak : Penelitian ini bertujuan untuk mendeskripsikan dan menjelaskan pengaruh tingkat pendidikan dan pengalaman kerja terhadap kinerja guru Sekolah Menengah Pertama Negeri 3 Baba Kecamatan Cendana Kabupaten Enrekang. Populasi penelitian ini adalah seluruh guru Sekolah Menengah Pertama Negeri 3 Baba Kecamatan Cendana Kabupaten Enrekang sebanyak 24 orang. Berdasarkan jumlah populasi yang hanya 24 orang, maka tidak ditarik sampel dalam artian penelitian populasi. Teknik yang digunakan dalam pengumpulan data adalah teknik observasi, angket, dokumentasi dan wawancara. Sedangkan teknik pengolahan data dilakukan dengan teknik statisitik infersial. Hasil penelitian menunjukkan bahwa: Gambaran tingkat pendidikan guru SMPN 3 Baba Kecamatan Cendana Kabupaten Enrekang memiliki tingkat pendidikan yang cukup memadai dalam hal ini dapat menunjang pekerjaan sehari-hari. Hal ini membuktikan bahwa guru SMPN 3 Baba Kecamatan Cendana Kabupaten Enrekang 100 persen memiliki tingkat pendidikan sarjana (S1) dalam hal ini dapat menunjang pekerjaan sehari-hari. Gambaran pengalaman kerja guru SMPN 3 Baba Kecamatan Cendana Kabupaten Enrekang cukup matang, hal ini dilihat dari lamanya mereka bekerja atau mengajar. Gambaran kinerja guru SMPN 3 Baba Kecamatan Cendana Kabupaten Enrekang berada pada kategori sangat tinggi. Terdapat pengaruh tingkat pendidikan, dan pengalaman kerja guru terhadap kinerja guru SMPN 3 Baba Kecamatan Cendana Kabupaten Enrekang.
\end{abstract}

Kata kunci : tingkat pendidikan, pengalaman kerja dan kinerja

\section{PENDAHULUAN}

Salah satu perhatian utama manajemen berbasis sekolah sebagai satuan pendidikan adalah peningkatan produktivitas kerja guru dan pegawai. Menurut Nawawi (2005) munculnya masalah produktivitas kerja dapat bersumber dari pengaruh hasil interaksi dari berbagai faktor. Salah satu faktor yang turut mempengaruhi produktivitas kerja adalah desain pekerjaan dari suatu organisasi yang tidak seimbang/sesuai dengan kemampuan pekerja itu sendiri (Werther \& Davis, 1989).

Penempatan seseorang pada suatu posisi tertentu sangat menentukan keberhasilan dalam pencapaian tujuan organisasi, tidak terkecuali posisi pimpinan ataupun administrator pada tingkat dasar sekalipun. Stoner dan Freeman (1992) mengungkapkan bahwa seberapa jauh sebuah organisasi mencapai tujuannya dan memenuhi kebutuhan masyarakat sangat tergantung pada baik tidaknya administrator organisasi tersebut dalam menjalankan pekerjaannya atau dengan kata lain dapat dikatakan bahwa jika para administrator organisasi menjalankan pekerjaannya dengan baik, maka organisasi yang dipimpinnya akan berhasil mencapai tujuannya, demikian pula sebaliknya 
suatu organisasi akan gagal mencapai tujuannya jika para administratornya tidak memiliki kompetensi yang memadai.

Pembicaraan tentang kinerja guru selalu menarik banyak orang untuk mendiskusikannya. Hal ini salah satu penyebabnya karena keberhasilan suatu organisasi akan banyak ditentukan oleh para tenaga pendidik (guru) dan pendidikan pengelola organisasi tersebut. Demikian pentingnya peranan seorang guru dalam suatu organisasi, maka dapat dikatakan bahwa jabatan guru merupakan posisi kunci bagi suatu organisasi. Dirinya merupakan pusat dari segala proses penggunaan sumber daya manusia. Dengan posisinya yang strategis dan menentukan itu, maka untuk dapat menjadi seorang guru yang efektif, disamping telah memiliki tingkat pendidikan, pengelaman kerja guru dan keterampilan yang sesuai dengan posisi dan eksistensi serta ruang lingkup bidang tugasnya, maka dituntut pula penguasaan beberapa aspek manajemen berbasis sekolah yang berkaitan dengan perilaku organisasi lainnya.

Dalam beberapa posisi manajerial tertentu di sekolah, mempersyaratkan jabatan guru dalam artian bahwa guru yang dianggap memiliki kompetensi tertentu diberikan tugas tambahan untuk memangkunya disamping tugas profesionalnya sebagai guru (Keputusan Presiden RI No. 199 Tahun 1998), padahal mereka sesungguhnya tidak dipersiapkan secara khusus untuk tugas tersebut. Oleh karena itu, dalam pelaksanaannya seringkali yang bersangkutan kurang memiliki pemahaman manajemen dan kemampuan manajerial yang sesungguhnya perlu dimiliki. Sebagai akibat dari kekurangan itu, tugas-tugas tersebut menjadi tidak dapat dilaksanakan dengan baik. Tugas-tugas tambahan yang diberikan kepada guru di luar tugas pokoknya terkadang menjadi terbalik sehingga tugas tambahan (administrasi tersebutlah yang banyak menyita tenaga dan waktu yang berakibat pada tidak maksimalnya pelaksanaan tugas pokok guru di sekolah.

Karena jabatan administratif yang dijabat oleh guru sebagai tugas tambahan bukan merupakan jabatan karir administratif yang dipersiapkan dengan baik, maka tidak menutup kemungkinan guru yang bersangkutan sesungguhnya kurang didukung dengan kemampuan tingkat pendidikan dan pengalaman kerja yang sangat terbatas terhadap bidang tugas pokok guru dalam meneningkatkan kinerja guru yang diembannya.

Keberhasilan pelaksanaan tugas atau kinerja seseorang sangat ditentukan oleh banyak faktor, diantaranya tingkat pendidikan, dan pengalaman kerja seseorang terhadap ruang lingkup wewenang, tugas, dan tanggungjawab yang menjadi bagian yang tak terpisahkan dari satu posisi atau jabatan tertentu. Sehubungan dengan itu Steers (1977:137) menyatakan bahwa "prestasi kerja individu merupakan fungsi gabungan dari tiga faktor penting yakni: (1) kemampuan, perangai, dan minat seorang pekerja, (2) kejelasan dan penerimaan atas penjelasan peranan seorang pekerja, dan (3) tingkat motivasi kerja". Berdasarkan pendapat tersebut, maka dapat dikatakan bahwa masing-masing faktor memiliki arti penting dalam menentukan tingkat hasil kerja tiap pekerja yang pada gilirannya membantu prestasi organisasi secara keseluruhan.

Relavansi tingkat pendidikan dan pengalaman kerja dengan bidang tugas yang akan dikerjakan oleh seseorang guru memberikan kontribusi yang sangat besar terhadap tingkat 
pendidikan dan pengalaman kerja seseorang mengenai bidang atau bagian tugas yang menjadi tanggung jawabnya sebagaimana dikemukakan oleh Becker dan Denison dalam Ordonez (1996) bahwa model sumber daya manusia merupakan kontribusi yang diberikan oleh pendidikan dan latihan untuk mewujudkan keterampilan manusia.

Berdasarkan pengamatan awal dan informasi dari beberapa orang guru di Sekolah Menengah Pertama Nenegi (SMPN) 3 Baba Kecematan Cendana Kabupaten Enrekang, dapat di tunjukkan adanya gejala pengisian posisi bidang studi seorang guru tidang sesuai dengan tingkat pendidikannya, dilakukan tanpa mempertimbangkan tanggung jawab di balik keahlian seorang guru. Ketertarikan mereka untuk berkompetisi untuk memperebutkan pemenuhan jam wajib mengajar guru. hal tersebut diperkirakan karena tingginya tunjangan professi guru yang akan diterima sesuai standar jam mengajar mereka yang dipersyaratkan yang mengiringi jabatan tersebut disamping karena prestise.

Dikemukakan oleh Sonhadji (2007) bahwa guru sangat menentukan perkembangan sekolah, karena mereka dapat mempengaruhi lingkungan intelektual dan sosial kehidupan sekolah. Pernyataan tersebut sangatlah rasional karena merekalah yang berkewajiban mengemban sebagian besar misi sekolah, mulai dari kegiatan tatap muka (belajar), sampai pada tugas-tugas yang lain, seperti pembinaan dan layanan bimbingan siswa maupun pengembangan institusional.

Kondisi seperti dikemukakan di atas tersebut dimungkinkan karena prioritas persyaratan untuk jabatan guru tersebut masih amat bersifat anatomis formal (terbatas pada pangkat/golongan, kualifikasi pendidikan, dan senioritas, serta usia), sedangkan persyaratan kemampuan akademik tidak menjadi prioritas.

Dengan mendasarkan diri pada latar belakang permasalahan di atas dan keinginan untuk membuktikan secara empirik berbagai penjelasan sebelumnya, maka penelitian ini dilakukan. Subyek penelitian ini adalah guru Sekolah Menengah Pertama Negeri (SMPN) 3 Baba Kecematan Cendana Kabupaten Enrekang.

\section{TELAAH LITERATUR DAN PENGEMBANGAN HIPOTESIS}

Konsep Pendidikan dan Urgensinya

Deklarasi dunia bagi pendidikan untuk semua orang yang menyatakan bahwa:

Semua orang, baik anak-anak, remaja, dan orang dewasa harus dapat memanfaatkan peluang mendapatkan pendidikan yang dirancang untuk memenuhi kebutuhan belajar mereka. Kebutuhan-kebutuhan belajar tersebut adalah termasuk sarana-sarana belajar terpenting (seperti keterwacanaan, ekspresi lisan, kemampuan berhitung, dan memecahkan persoalan) dan muatan belajar tingkat dasar (seperti pengetahuan, keterampilan, tata nilai, dan sikap perilaku) yang diperlukan manusia agar dapat mempertahankan eksistensinya di dunia, mengembangkan kapasitas diri mereka sepenuhnya, agar dapat hidup dan bekerja dengan penuh martabat, agar dapat berperan serta secara aktif dalam pembangunan, meningkatkan taraf hidup mereka, dan dapat membuat keputusan intelektual dan melanjutkan studi mereka ke tingkat lanjut (Ordonez, 1996:1)

Postman dan Weingartner dalam Syarifuddin (2007:217) menyatakan bahwa secara sederhana, pendidikan adalah "proses yang panjang untuk 
belajar bagaimana bernegosiasi dengan dunia". Ini berarti bahwa pendidikan berlangsung seumur hidup, yakni berlangsung sebelum memasuki sekolah dan akhirnya setelah sekolah. Hal ini seperti yang di ungkapkan oleh Rusdinal (2007) bahwa proses belajar tidak harus dilakukan melalui pendidikan di sekolah, sehingga pendidikan informal juga merupakan bagian dari proses pendidikan.

Unsur-unsur yang berperan dalam peningkatan profesionalisme guru diantaranya adalah KKG/MGMP, LPMP/P4TK, Kepala Sekolah, Pengawas Sekolah dan Pemerintah.

\section{Masalah yang Dihadapi Guru}

Mutu pendidikan tidak hanya ditentukan oleh lembaga pendidikan yang biasa disebut sekoalah atau perguruan tinggi melainkan juga ditentukan para pendidik/guru/dosen yang berkualitas dalam menyelenggarakan berbagai aktivitas yang berkaitan dengan pendidikan. Kenyataan profesi guru lebih banyak dipilih sebagai alternatif kedua atau bahkan pilihan terakhir bagi pencari kerja. Hal itu tidak terlepas dari banyaknya permasalahan yang muncul mulai dari nasib guru, yang selalui menjadi perbincanagan umum karena kelak akan mengalami kesulitan dalam memenuhi kebutuhan hidup, bahkan guru itu sendiri, hingga sestem pendidikan akhir-akhir ini semakin diragukan kualitasnya.

\section{Pendidikan Merupakan Faktor Kunci dalam Membentuk Manusia.}

Guru memegam peran sentral dalam proses belajar mengajar, untuk itu mutu pendidikan di suatau sekolah sangat ditentukan oleh kemampuan yang dimiliki seorang guru dalam menjalankan tugasnya. Menurut Aqil (2002) guru adalah faktor penentu bagi keberhasilan pendidikan di sekolah.
Sikap guru menurut Husen (1995) terhadap pekerjaan dapat dilihat dalam bentuk persepsi dan kepuasannya dalam terhadap pekerjaan maupun dalam bentuk motovasi kerja yang ditampilkan.

\section{Kebutuhan Guru yang Profesional}

Dimasa depan, dengan tantangan zaman yang begitu kompleks, perkembangan tegnologi yang begitu cepat, setta situasi pendidikan yang tidak mudah, jelas dibutuhkan guruguru yang lebih profesional dan bermutu. Di lapangan, menurut Hammand dan Youngs (2002) keluhan terhadap lulusan pendidikan guru adalah kurangnya penguasan bidang ilmu dan profesional ketika mengajar.

\section{Sertifikasi Guru dan Peningkatan Mutu Pendidikan}

Bagi Indonesia dalam rencana strategisnya melalui undang-undang dan peraturan pemerintah telah mengatur beberapa langkah untuk meningkatkan mutu guru, khususnya dengan memberi sertifikasi kepada guru yang memeiliki kualifikasi dan kompetensi yang sesuai mata pelajaran yang diajarkannya. Serifikasi merupakan proses pemberian sertifikat sebagai pendidik bagi seorang melalui pendidikan tertentu. Adapun sertifikat pendidik adalah bukti formal sebagai pengakuan yang diberikan kepada guru sebagai tenaga profesional.

\section{Guru dan Masa Depan Pendidikan}

Kesadaran baru guru dan juga kesadaran para pengelola kebijakan pemerintah akan membantu untuk terus mengembangkan dunia pendidikan di Indonesia ke depan. Akan tetapi, yang teramat penting untuk diperhatikan adalah kesejahteraan guru sebagai ujung tombak bagi kebangkitan dunia pendidikan di tanah air kita ini. "Secara resmi dan legal, pendidikan 
formal merupakan porsi negara atau fungsi negara. Sebab dalam penyelenggaraan sistem pendidikan negara mempunyai kekuasaan resmi dan sarana yang diperlukan untuk mengarahkan pelaksanaan pendidikan" (Kartono, 1991:108). Dalam hal ini kedudukan negara sangat penting, sebab "pendidikan dapat dijadikan sebagai alat untuk merealisasikan tujuan negara dan menghidupkan negara yang bersangkutan" (Stoddard, dalam Uwes 1999). Dengan demikian, sistem pendidikan nasional merupakan alat sekaligus tujuan yang teramat penting dalam perjuangan untuk mencapai cita-cita dan tujuan nasional. Tidaklah berkelebihan kiranya manakala dikatakan kemajuan suatu negara dapat dilihat dari kemajuan pendidikan negara yang bersangkutan, demikian pula sebaliknya.

\section{Pengalaman Kerja}

Mengenai berapa lama pengalaman kerja minimal yang harus dimiliki oleh seseorang untuk diangkat menjadi pimpinan atau manajer dalam suatu organisasi tertentu masih belum ada yang pasti, namun dari beberapa pendapat seperti (Mark, Stoops \& King, 1985; Nawawi, 2005; Wiles \& Bondi, 2000) mengemukakan pengalaman kerja dua tahun. Demikian pula Mc Kean dan Miles (dalam Syarifuddin, 2007) menentukan pengalaman minimal bagi seorang guru untuk dapat berhasil dalam melaksanakan tugasnya setelah diangkat menjadi guru di sekolah sekurang-kurangnya memiliki masa kerja tiga sampai lima tahun. Beberapa pendapat tersebut diperkuat pula oleh hasil penelitian Roch dan Hemphill (dalam Campbell, 1983) yang mengemukakan bahwa disamping mempunyai pengalaman dalam bidang administrasi dan supervisi, seorang pimpinan lembaga pendidikan hendaknya pernah mengajar antara tujuh sampai sembilan tahun.

Terlepas dari adanya perbedaan tentang pengalaman kerja seseorang sebelum diangkat menjadi seorang pimpinan, Hall \& Louck (1977) melaporkan hasil penelitaiannya yang menunjukkan bahwa pengalaman mengajar berpengaruh terhadap penerapan pembaharuan pendidikan. Selain itu, penelitian yang dilakukan oleh Michigan University (1985) menunjukkan adanya hubungan positif antara tingkat pendidikan dan pengalaman kerja (masa kerja) dengan perilaku guru, demikian pula dengan penelitian Arowono (2000) yang juga menemukan adanya hubungan yang signifikan antara pendidikan formal, pendidikan in-service, dan pengalaman kerja dengan kualitas mengajar seorang guru.

Seorang manajer pendidikan yang memiliki pengetahuan dan pengalaman yang cukup dalam bidangnya seperti yang dikemukakan oleh Nawawi (2005) juga memiliki kemampuan melihat kedepan dalam peningkatan perkembangan organisasi sekolah yang dipimpinnya. Di samping itu pengetahuan dan penagalaman kerja yang cukup bagi seorang pimpinan akan memiliki juga kematangan kerja yang tinggi. Sarojo (1990) menegaskan bahwa pemimpin yang memiliki kematangan kerja (kecakapan) tinggi di dalam bidangnya memiliki juga pengetahuan, kepandaian, dan pengalaman untuk melakukan tugas tanpa tergantung dari pengaruh orang lain. Dengan demikian, maka jelaslah bahwa pengalaman kerja adalah pelajaran yang akan menghasilkan perubahan ke arah kematangan tingkah laku, pertambahan pengertian serta pengayaan informasi (Surachmad, 2000). Oleh sebab itu, menurut Nawawi (2005) menyatakan bahwa 
berbagai pengalaman masa lalu akan sangat berguna dalam mendukung pengetahuan yang dimiliki bilamana seorang guru, pimpinan atau manajer pendidikan menghadapi masalahmasalah baru. Melalui pengalaman kerja yang cukup panjang bagi seorang guru, dan pimpinan diharapkan dapat menjadi guru, dan manajer pendidikan yang sukses dalam mengelola lembaga pendidikan yang diembannya.

Belajar dari berbagai pengalaman kerja dalam jabatan dan rentang waktu panjangnya pengalaman mengajar akan semakin mempermantap kematangan pribadi seseorang dalam menjalankan tugas dan tanggung jawabnya sebagai seorang guru atau manajer pendidikan. Pengalaman kerja yang dilalui seseorang akan membantu yang bersangkutan untuk menentukan langkah-langkah tertentu yang dapat menunjang keberhasilan kerja, demikian juga hal-hal yang harus di hindari karena akan menjadi penghambat dan berujung pada kegagalan dalam melaksanakan tugasnya.

\section{Kinerja Guru}

Snell (1992) menyatakan bahwa kinerja merupakan kulminasi dari tiga elemen yang saling berkaitan, yakni keterampilan, upaya, dan sifat keadaan eksternal. Tingkat keterampilan merupakan bahan mentah yang dibawa oleh seorang karyawan ke tempat kerja seperti pengetahuan, kemampuan, kecakapan-kecakapan interpersonal serta kecakapan-kecakapan teknis. Tingkah upaya, dapat digambarkan sebagai motivasi yang diperlihatkan karyawan untuk menyelesaikan pekerjaan, sedangkan kondisi-kondisi eksternal mendukung produktivitas kinerja.

Lowler (1984) menyatakan bahwa kinerja guru berhubungan dengan kemampuan dan kecakapan melakukan sesuatu. Selanjutnya, Kast dan Rosenzweig (1979) yang didukung oleh Hoy dan Miskel (1978) menyatakan bahwa kinerja guru merupakan suatu kemampuan dalam melaksanakan tugas atau pekerjaan yang sesuai dengan sikap, pengetahuan, dan keterampilan serta motivasi. Pendapat ini senada dengan yang dikemukakan Vroom dan Deci (1970) bahwa kinerja seseorang dalam mengerjakan sesuatu pekerjaan, berkaitan dengan kemampuan atau keterampilan orang tersebut dalam menggunakan kemampuan dan keterampilannya ketika melaksanakan pekerjaan yang dibebankan kepadanya.

Dalam studi kepustakaan seperti dinyatakan Bolton (1973) bahwa kinerja guru dalam mengajar dibentuk dan dikembangkan oleh banyak faktor antara lain faktor personal guru, situsional, hubungan antara manusia di sekolah, bahan dan sumber belajar, siswa yang belajar, kondisi fisik yang ada, keadaan sosial ekonomi, dan faktor psikologi lainnya. Dari sudut psikologi, kinerja guru dapat dikatakan sebagai tingkah laku kerja seseorang, yang pada akhirnya dihasilkan sesuatu yang menjadi tujuan dari pekerjaannya. Oleh karena itu, untuk menganalisis kinerja guru dapat dilakukan secara menganalisis karakteristik perilaku kinerja yang diperlihatkannya. Karakteristik tersebut antara lain: (a) pelaksanaan tugas yang sesuai dengan harapan organisasi, (b) menggunakan peralatan yang tersedia, (c) mempunyai semangat tinggi, (d) mempunyai hubungan kerjasama yang baik dengan atasan dan sejawat, dan (e) dapat mengatasi masalah yang berkaitan dengan tugas yang dilaksanakan setiap hari.

Produktivitas suatu organisasi banyak ditentukan oleh kinerja anggota. Kinerja menurut Steers (1983) adalah suatu tingkat pada saat 
seseorang berhasil menyelesaikan tugas tertentu. Nadler (1987) mengartikan kinerja sebagai unsurunsur perilaku yang ditampilkan oleh seseorang sehubungan dengan pekerjaannya. Selanjutnya, Nadler menggunakan istilah kinerja bergantian dengan istilah perilaku, secara umum kinerja dapat dikatakan sebagai perilaku atau aktivitas seseorang dalam melakukan tugas-tugas atau tanggung jawabnya sebagai anggota organisasi dalam upaya untuk mencapai efektivitas dan efisiensi organisasi. Budaya organisasi mengacu kepada nilai, norma perilaku, kepercayaan, kebiasaan serta filosofi organisasi, sedangkan iklim organisasi lebih menekankan kepada persepsi seseorang tentang gambaran mengenai norma perilaku Owens dalam Hasri (2004). Guru adalah anggota organisasi sekolah yang tugas utamanya adalah mengajar, oleh karena itu, kinerja yang harus ditunjukkan oleh seseorang guru adalah menyangkut pekerjaan utamanya, yakni mengajar. Bahkan, akuntabilitas masyarakat di luar dan di dalam lingkup sekolah di fokuskan pada kinerja guru (Haris, 1979). Dari uraian tersebut, dapat disimpulkan bahwa yang dimaksud kinerja guru adalah hasil kerja guru dalam melaksanakan tugas dan tanggung jawabnya sebagai anggota organisasi dalam upaya mencapai tujuan sekolah.

\section{Kompetensi Guru}

Jika mengacu pada pengukuran kinerja, kompetensi merupakan kapasitas yang ditampilkan individu dalam berbagai cara; bila dikaitkan dengan tugas, kompetensi sebagai kinerja difokuskan pada perilaku (Harris, 1979). Harris menekankan kompetensi dalam tugas, peran, dan tanggung jawab guru yang terkait dalam kegiatan pengajaran. Sebagai kapabilitas yang akan dilakukan, kompetensi mengacu pada perilaku tertentu, paling tidak pada kondisi dan waktu tertentu.

Adapun kompetensi guru adalah kemampuan melakukan tugas mengajar dan mendidik yang diperoleh melalui pendidikan dan pelatihan (Sahertian, 1994). Sebelum menentukan kriteria evaluasi kinerja profesional guru, persoalan mengajar yang efektif merupakan sesuatu yang esensi untuk dijelaskan. Hal ini mengingat pekerjaan mengajar merupakan kinerja guru yang akan dinilai. Owens (1994) mengatakan bahwa guru efektif dalam mengajar, jika: (1) memiliki keahlian, (2) aktual dalam mengajar, (3) perilaku guru difokuskan pada pebelajar misalnya prestasi siswa, dan (4) sesuai dengan kesepakatan profesional di masingmasing negara.

\section{Pengukuran Kinerja Guru}

Kinerja guru merupakan tindakantindakan atau pelaksanaan tugas yang dapat diukur (Seymour, 1991). Hal ini dapat dikatakan berkaitan dengan jumlah kuantitas dan kualitas yang dapat diselesaikan oleh individu dalam kurun waktu tertentu. Dalam proses pengukuran kinerja guru, masalah yang paling pokok adalah menetapkan kriterianya sebagai standar. Menurut Jessup \& Jessup (1975), yang pertama diperlukan dalam hal ini adalah ukuran mengenai sukses, dan bagian-bagian mana yang dianggap lebih penting dalam suatu pekerjaan. Usaha menentukan ukuran tentang sukses ini amatlah sulit, karena seringkali pekerjaan itu begitu kompleks sehingga tak ada ukuran yang pasti. Hal seperti ini terutama terdapat pada jabatan-jabatan yang bersifat administratif. Kesulitan dalam menentukan dasar ukuran ini merupakan masalah yang sensitif di kalangan ahli psikologi industri, dan 
biasa dikenal dengan sebutan the criterion problem (Wexley \& Yukl, 1977).

Agar supaya memudahkan pengukuran kinerja guru, Maier (1985) membagi pekerjaan menjadi dua jenis, yaitu (1) Pekerjaan produksi, dimana secara kuantitatif orang bisa membuat suatu standar yang objektif, (2) Pekerjaan bukan produksi, dimana penentuan sukses tidaknya seseorang di dalam tugas biasanya di dapat melalui human judgements atau pertimbangan subjektif. Untuk jenis pertama, hasil produksi seseorang bisa langsung dihitung, dan mutunya dapat dinilai pula melalui pengujian hasil. Sementara itu jenis yang kedua ada berbagai cara yang lazim ditempuh, antara lain melalui rating oleh atasan, rating oleh kawan (peer rating) dan self rating.

Mengingat cara ini lebih bersifat subjektif, maka sedapat mungkin diusahakan adanya standar yang objektif itu, dan kalau sudah tidak mungkin, barulah ke langkah yang kedua. Pendek kata, pengukuran tentang kinerja guru itu tergantung kepada jenis pekerjaannya dan tujuan dari organisasi yang bersangkutan. Kedua hal ini menentukan apa kriteria sukses yang berlaku untuk jabatan itu, dan dimensi-dimensi mana dari pekerjaan itu yang dianggap lebih penting.

Berkaitan dengan standar kinerja guru tersebut, Simamora (1997), mengemuka-kan beberapa persyaratan yang harus dipenuhi, yaitu: (1) Standar kinerja guru haruslah relevan dengan individu dan organisasi, (2) Standar kinerja guru haruslah stabil dan dapat diandalkan, (3) Standar kinerja guru haruslah membedakan antara pelaksana pekerjaan yang baik, sedang, atau buruk, (4) Standar kinerja guru haruslah dinyatakan dalam angka, (5) Standar kinerja guru haruslah mudah diukur, (6) Standar kinerja guru haruslah dipahami oleh guru dan penyelia, (7) Standar kinerja guru haruslah memberikan penafsiran yang tidak mendua.

\section{METODE PENELITIAN}

\section{Definisi Operasional}

Variabel - variabel dalam penelitian ini di definisikan sebagai berikut :

a) Tingkat pendidikan formal adalah proses yang mengajarkan manusia untuk menghadapi lingkungannya secara sadar, sistematis, dan berencana yang diorganisasikan dalam suatu sistem penjengjangan dari pendidikan dasar, pendidikan menengah, dan pendidikan tinggi. Indikatornya adalah tingkatan pendidikan formal yang dilaksanakan.

b) Pengalaman kerja adalah rentang waktu lamanya seseorang menjadi guru. Lamanya bekerja tersebut dapat dilihat dari banyaknya tahun, yaitu sejak tahun pertama kali diangkat menjadi guru.

c) Kinerja Guru adalah prestasi kerja yang dicapai seorang guru setelah menyelesaikan tugasnya dalam bidang profesi, kemanusiaan, dan kemasyarakatan. Indikator yang diukur adalah perencanaan pengajaran, pengelolaan pengajaran, dan penilaian hasil pembelajaran.

\section{HASIL PENELITIAN DAN PEMBAHASAN}

\section{Uji Normalitas Data}

Uji normalitas data dimaksudkan untuk mengetahui kenormalan data tentang tingkat pendidikan, iklim organisasi dengan Motivasi. Pengujian kenormalan data digunakan dengan kriteria bila Chi-square $\left(X_{\square}^{2}\right)$ lebih kecil atau sama dengan harga Chi 
kuadrat tabel $\left(X_{\square}^{2} \leq X_{t}^{2}\right)$, maka distribusinya dinyatakan normal.

\begin{tabular}{|lrlllll|}
\hline Variabel & Dk & $X_{\square}^{2}$ & $X_{t}^{2}$ & Sig. & Keterangan \\
\hline X1 & 13 & 21,111 & 37,652 & 0,995 & Normal \\
X2 & 13 & 20,111 & 37,652 & 0,995 & Normal \\
Y & 13 & 22,44 & 24,996 & 0,935 & Normal \\
\hline
\end{tabular}

Sumber: Hasil analisis data melalui SPSS 18.0
Perhitungan persamaan regresi yang terdapat pada lampiran diperoleh nilai $\mathrm{a}=18,843$ dan $\mathrm{b}=0,564$ sehingga persamaan regresinya adalah:

$$
\mathrm{Y}=-1.025+0,546+0,514 \mathrm{x}
$$

Berdasarkan perhitungan persamaan regresi untuk menguji hipotesis dari hasil SPSS 18.0 diperoleh data pada tabel berikut:

\section{Analisis Regresi Linear Sederhana}

Tabel 7 Pengujian hipotesis

\section{Coefficients}

\begin{tabular}{|c|c|c|c|c|c|c|}
\hline \multirow{2}{*}{\multicolumn{2}{|c|}{ Model }} & \multicolumn{2}{|c|}{$\begin{array}{l}\text { Unstandardized } \\
\text { Coefficients }\end{array}$} & \multirow{2}{*}{$\begin{array}{c}\text { Standardized } \\
\text { Coefficients } \\
\text { Beta }\end{array}$} & \multirow[b]{2}{*}{$\mathrm{t}$} & \multirow[b]{2}{*}{ Sig. } \\
\hline & & $B$ & Std. Error & & & \\
\hline \multirow[t]{3}{*}{1} & (Constant) & -1.025 & 2.965 & & -.346 & .732 \\
\hline & Tingkat Pendidikan & .549 & .129 & .418 & 4.246 & .000 \\
\hline & Pengalaman kerja & .514 & .073 & .692 & 7.033 & .000 \\
\hline
\end{tabular}

a. Dependent Variable: Kinerja guru

Berdasarkan tabel diatas hasil perhitungan taraf signifikan $0,000<$ 0,05, maka Hi diterima yang berarti ada sifat ketergantungan variabel tingkat pendidikan, dan pengalaman kerja dengan kinerja guru, atau dapat dikatakan bahwa hipotesis dalam peneltian ini adalah diterima dari hasil analisis SPSS.18.0 di atas ternyata signifikan untuk variabel kinerja guru adalah 0,009 jauh dibawah 0,05, karena itu $\mathrm{Hi}=$ koefisien regresi signifikan. Dengan demikian hubungan tingkat pendidikan, dan pengalaman kerja dengan kinerja guru.

\section{Pembahasan}

Tingkat pendidikan adalah jenjang pendidikan formal yang dilalui oleh setiap orang termasuk orang tua yaitu ayah dan ibu dari seseorang atau beberapa orang dan mendapatkan ijazah, dalam prosesnya memerlukan waktu dan biaya. Menurut Undangundang nomor 20 Tahun 2003 tentang sistem pendidikan nasional dijelaskan bahwa jenjang pendidikan adalah tahapan pendidikan yang ditetapkan berdasarkan tingkat perkembangan peserta didik, tujuan yang ingin dicapai dan kemampuan yang dikembangkan.

$$
\text { Jenjang atau tingkatan }
$$

pendidikan formal yang ada yang harus dilalui oleh seseorang adalah mulai jenjang pendidikan dasar sampai pendidikan tinggi. Berdasarkan jenjang pendidikan tersebut menunjukkan bahwa semakin tinggi seseorang memperoleh pendidikan maka pengalamannya pun semakin banyak dalam dunia pendidikan. Dan sebaliknya semakin rendah jenjang pendidikan yang dilalui seseorang semakin sedikit pula pengalaman dan pengetahuan yang dimiliki dan biaya yang dikeluarkan seseorang untuk memperoleh pendidikan, semakin sedikit pula. Hal inilah yang menjadi pengalaman seorang pegawai negeri dalam melaksanakan tugasnya. Jadi 
pengalaman pendidikan seseorang merupakan pengalaman tersendiri dari orang tua tersebut untuk mendidik anak-anaknya dan pengalaman inilah yang dapat dijadikan selanjutnya untuk menentukan kualitas dari seseorang untuk mendidik anaknya.

Pengalaman kerja pada hakekatnya merupakan rangkuman pemahaman terhadap apa yang dialami seseorang dalam pekerjaannya, sehingga apa yang dialami tersebut merupakan miliknya. Pengalaman kerja merupakan akumulasi dari lamanya guru Sekolah Menengah Pertama Negeri (SMPN) 3 Baba Kecamatan Cendana Kabupaten Enrekang dalam melaksanakan tugasnya, sehingga apa yang telah dialami dalam melaksanakan tugas tersebut akan menjadi suatu hal yang berguna baginya dalam melaksanakan tugas di masa yang akan datang.

Pengalaman kerja yang dimaksud adalah masa kerja atau lamanya seseorang guru dan atau pegawai dalam menekuni pekerjaannya. Maksudnya adalah masa kerja guru dan pegawai yaitu sejak dinyatakan menjadi guru oleh menteri pendidikan nasional, menteri agama atau lembaga pendidikan yang didirikan oleh masyarakat melalui Surat Keputusan (SK). Dengan demikain masa kerja berarti seseorang yang menjalankan tugas sesuai dengan profesinya yang dimulai sejak berlakunya surat keputusan tersebut. Seseorang yang baru terjun ke dunia kerja sesuai dengan profesinya dalam hal ini pegawai, maka pada saat itu merupakan awal dari pengalamannya melaksanakan pekerjaan dan akan berlanjut terus sepanjang masa tugasnya. Proses pengalaman karir pegawai diwarnai oleh berbagai pengalaman yang menyangkut profesinya tersebut. Makin lama masa kerja seseorang semakin banyak pula pengalaman yang didapatkannya.

Pengalaman-pengalaman yang didapatkannya itu merupakan proses belajar bagaimana tindakan selanjutnya yang lebih baik agar pekerjaannya itu dapat dilaksanakan secara efektif dan efisien. Untuk mengetahui hubungan tingkat pendidikan, dan pengalaman kerja dengan kinerja guru Sekolah Menengah Pertama Negeri (SMPN) 3 Baba Kecamatan Cendana Kabupaten Enrekang dapat dilihat hasil analisis data pada lampiran.

Berdasarkan hasil analisis data yang diperoleh, bahwa pengalaman kerja mempunyai hubungan sebesar $0,220 \%$ pada taraf signifikansi $0,05 \%$ berada dalam kategori hubungan rendah dengan kinerja guru SMPN 3 Baba Kecamatan Cendana Kabupaten Enrekang. Dalam hal ini sumbangsih pengalaman kerja dengan kinerja guru sangat rendah, ini disebabkan karena beban pekerjaan yang ada adalah pekerjaan guru yang sudah rutinitas di lakukan, yang umum atau lazim yang hanya butuh waktu tidak terlalu lama untuk mempelajarinya dan semua orang akan bisa melakukan pekerjaan tersebut.

Karena jabatan administratif yang dijabat oleh guru sebagai tugas tambahan bukan merupakan jabatan karir yang dipersiapkan dengan baik, maka tidak menutup kemungkinan guru yang bersangkutan sesungguhnya kurang didukung dengan kemampuan tingkat pendidikan dan pengalaman kerja yang sangat terbatas terhadap bidang tugas pokok guru dalam meneningkatkan kinerja guru yang diembannya di sekolah.

Keberhasilan pelaksanaan tugas atau kinerja seseorang sangat ditentukan oleh banyak faktor, diantaranya tingkat pendidikan, dan pengalaman kerja seseorang terhadap 
ruang lingkup wewenang, tugas, dan tanggungjawab yang menjadi bagian yang tak terpisahkan dari satu posisi atau jabatan tertentu. Sehubungan dengan itu Steers (1977:137) menyatakan bahwa "prestasi kerja individu merupakan fungsi gabungan dari tiga faktor penting yakni: (1) kemampuan, perangai, dan minat seorang pekerja, (2) kejelasan dan penerimaan atas penjelasan peranan seorang pekerja, dan (3) tingkat motivasi kerja. Pada dasarnya kinerja merupakan suatu proses pencapaian suatu hasil kerja. Para ahli telah banyak mengemukakan pendapatnya tentang kinerja, baik secara etimologi maupun terminologi. Dalam kamus besar bahasa Indonesia edisi kedua, kinerja diartikan sebagai "Seseuatu yang dicapai, prestasi yang diperlihatkan, kemampuan kerja" (Depdiknas, 1994:503). Maier (dalam As'ad, 2005) mengatakan bahwa kinerja merupakan kesuksesan seseorang di dalam melaksanakan suatu pekerjaan. Menurut Bateman (1992) kinerja adalah proses kerja seorang individu untuk hasil-hasil tertentu. Lebih lanjut dijelaskan bahwa kinerja seseorang dipengaruhi oleh dua faktor internal meliputi kemampuan dan upaya serta faktor eksternal yang meliputi kesulitan tugas dan keberuntungan.

Kinerja dalam kajian manajemen dapat kita lihat seperti yang dikemukakan oleh Schermerhon (dalam Hamid, 2000:11) mengemukakan bahwa "Kinerja secara formal didefinisikan sebagai kualitas dan kuantitas dari pencapaian tugastugas atau pekerjaannya sesuai dengan standar, kriteria, dan ukuran yang ditetapkan untuk pekerjaan itu".

Prawiro sentono menyatakan bahwa: Performance atau kinerja adalah hasil kerja yang dapat dicapai oleh seseorang atau sekelompok orang dalam suatu organisasi sesuai dengan wewenang dan tanggung jawab masing-masing dalam rangka upaya dalam mencapai tujuan organisasi bersangkutan sesuai dengan moral dan etika.

Dari pengertian kinerja di atas dapat ditarik kesimpulan bahwa kinerja atau performance merupakan hasil kerja yang dapat dicapai oleh seseorang atau sekelompok orang dalam organisasi, sesuai dengan wewenang atau tanggung jawab masing-masing dalam rangka mencapai tujuan organisasi yang bersangkutan.

Kinerja dalam konteks pengajaran menurut Gross (dalam Idris, 2001) mencakup hal-hal: (1) prestasi (achievement) dan penghargaan prestasi yang memberi kesempatan untuk meningkatkan pengetahuan, (2) tanggung jawab (responsibility) yang memberi kesempatan untuk pemahaman, (3) kemungkinan untuk bertumbuh dan promosi (possibility of growth advancement) yang memberi kesempatan kemenduaan (ambiguity) pengalaman dalam pembuatan keputusan, (4) minat pada pekerjaan yang memberikan kesempatan individu tumbuh secara nyata.

Hasibuan (2002: 94) mengatakan: Prestasi kerja adalah suatu hasil kerja seseorang dalam melaksanakan tugastugas yang dibebankan kepadanya yang di dasarkan atas kecakapan, pengalaman, dan kesanggupan serta waktu. Sedangkan Robbins (1996:83) "Kinerja seseorang dapat ditingkatkan apabila ada kesesuaian antara pekerjaan dan kemampuan." Jadi guru harus mengajar mata pelajaran yang sesuai dengan bidang keahliannya.

Mengajar dan mendidik adalah salah satu pekerjaan profesi yang memiliki tujuan, merupakan suatu

Corresponding Author: muhammad_nadhar@yahoo.com 
aktivitas yang menuntut beberapa peran dan fungsi untuk mencapai tujuan pendidikan dan pengajaran yang maksimal. Menurut Davis (dalam Hamid, 2002:21) "Peran dan tugas guru dapat diidentifikasi dalam dua bagian pokok yaitu: guru sebagai pengelola, dan guru sebagai pelaksana." Peran dan fungsi guru sebagai pengelola menuntut suatu kemampuan manajerial dalam mengelola pendidikan dan pengajaran, sedangkan guru sebagai pelaksana menuntut guru memiliki kemampuan teknis dalam melaksanakan kegiatan belajar mengajar di kelas. Pendapat senada diungkapkan Usman (2002:9) bahwa "Guru yang kompoten akan lebih mampu mengelola kelasnya sehingga hasil belajar siswa berada pada tingkat optimal."

Sehubungan dengan pendapat di atas, Ali (dalam Usman, 2002:15) mengungkapkan bahwa: Profesi guru harus memenuhi persyaratan khusus sebagai berikut:

(1) Menuntut adanya keterampilan yang berdasarkan konsep dan teori ilmu pengetahuan yang mendalam, (2) menekankan pada suatu keahlian dalam bidang tertentu sesuai dengan profesinya, (3) menuntut adanya tingkat pendidikan keguruan yang memadai, (4) adanya kepekaan terhadap dampak kemasyarakatan dari pekerjaan yang dimilikinya, dan (5) kemungkinan perkembangan sejalan dengan dinamika kehidupan.

Djamarah (1994) dikatakan bahwa peran dan fungsi guru sebagai pengelola, diuraikan dalam kompotensi guru yang dikenal sebagai kemampuan dasar guru yang sekaligus menjadi tolak ukur atau standar kerja guru. Standar kinerja guru tersebut adalah sebagai berikut: (1) guru dituntut menguasai bahan ajar, (2) guru mampu mengelola program belajar mengajar, (3) guru mampu mengelola kelas, (4) guru mampu menggunakan media dan sumber mengajar, (5) guru menguasai landasan-landasan pendidikan, (6) guru mampu mengelola interaksi belajar mengajar (7) guru mampu menilai prestasi siswa untuk kepentingan pengajaran, (8) guru mengenal fungsi serta program pelayanan bimbingan dan penyuluhan, (9) guru mengenal dan menyelenggarakan administrasi sekolah, (10) guru memahami prinsipprinsip dan menafsirkan hasil penelitian pendidikan guru keperluan pengajaran.

Selanjutnya Usman (2002) menambahkan persyaratan yang harus dipenuhi oleh setiap pekerjaan yang tergolong ke dalam suatu profesi antara lain: (1) memiliki kode etik, sebagai acuan dalam melaksanakan tugas dan fungsinya, (2) memiliki klien/objek layanan yang tetap, seperti dokter dengan pasiennya, guru dengan muridnya, dan (3) diakui oleh masyarakat karena memang diperlukan jasanya di masyarakat.

Atas dasar persyaratan tersebut, jelas jabatan profesional seperti guru harus ditempuh melalui jenjang pendidikan khusus. Sejalan dengan pendapat Usman, Sardiman (1986:126) mengatakan:

Kemampuan-kemampuan professional meliputi hal-hal berikut:

(1) menguasai landasan pendidikan, (2) menguasai bahan pengajaran, (3) menyusun program pengajaran, (4) melaksanakan program pengajaran, dan (5) menilai hasil dan proses belajar mengajar yang telah dilaksanakan. Selain itu guru dalam melaksanakan tugasnya harus menguasai keterampilan mengajar yang terdiri dari: (1) keterampilan bertanya (questioning skill), 
keterampilan memberi penguatan (reinforcement skill),

keterampilan mengadakan variasi (variation skill), (4) keterampilan menjelaskan (exaplaining skill), (5) keterampilan membuka dan dan menutup pelajaran (set induction and closure), (6) keterampilan membimbing diskusi kelompok kecil, (7) keterampilan mengelola kelas, (8) keterampilan mengajar perseorangan.

Untuk mengukur kinerja seseorang dalam bidangnya Robbins (1986) mengungkapkan bahwa hasil perbandingan antara hasil evaluasi terhadap pekerjaannya dengan kriteria yang telah ditetapkan bersama. Selanjutnya ia mengemukakan beberapa karakteristik, seseorang yang memilki kinerja yaitu: (1) memiliki rasa percaya diri, (2) selalu berorientasi pada prestasi, (3) kontrol diri yang tinggi, (4) memiliki kemampuan, dan (5) berusaha terus untuk mencapai sasaran organisasi yang lebih baik.

Zainun (1989:50) mengemukakan faktor yang dapat mempengaruhi kinerja yaitu: "(1) Hubungan yang harmonis antara pemimpin dan bawahan, (2) kepuasan terhadap pekerjaan, (3) iklim kerja yang sehat dan bersahabat, (4) rasa kemanfaatan tujuan organisasi, (5) adanya tingkatan kepuasan ekonomi materiil, (6) adanya ketenangan jiwa, jaminan, serta perlindungan bagi karyawan." Dalam perspektif manajemen, agar kinerja guru dapat ditingkatkan dan mencapai standar tertentu, maka dibutuhkan suatu manajemen kinerja. Menurut Robert Bacal (dalam Sulaimanzen, 2007) mengatakan: ... sebuah proses komunikasi yang berkesinambungan dan dilakukan dalam kemitraan antara seorang karyawan dan penyelia langsungnya.

Proses ini meliputi kegiatan membangun harapan yang jelas serta pemahaman mengenai pekerjaan yang akan dilakukan. Ini merupakan sebuah sistem. Artinya, ia memiliki sejumlah bagian yang semuanya harus diikutsertakan, kalau sistem manajemen kinerja hendak memberikan nilai tambah bagi organisasi, manajer dan karyawan. Terbentuknya sinergi baru dalam lingkungan persekolahan, adalah terjadinya kinerja yang efektif dan efesien disetiap struktur yang ada dipersekolahan. Kinerja terbentuk bilamana masing-masing struktur memiliki tanggung jawab dan memahami akan tugas dan kewajiban masing-masing.

Ukuran kinerja guru terlihat dari rasa tanggung jawab menjalankan amanah, profesi yang diembannya, dan rasa tanggung jawab moral dipundaknya. Semua itu akan terlihat kepada kepatuhan dan loyalitas di dalam menjalankan tugas keguruannya di dalam kelas dan tugas kependidikannya di luar kelas. Sikap ini akan dibarengi pula dengan rasa tanggung jawab mempersiapkan segala perlengkapan pengajaran sebelum melaksanakan proses pembelajaran. Selain itu, guru juga akan mempertimbangkan metedologi, alat media, dan alat penilaian yang akan digunakan (Isjoni, 2004).

Kinerja guru akan optimal, bilamana diintegrasikan dengan komponen persekolahan, apakah itu kepala sekolah, guru, karyawan, maupun anak didik. Kinerja guru akan bermakna bila dibarengi dengan nawaitu yang bersih dan ikhlas, serta selalu menyadari akan kekurangan yang ada pada dirinya, dan berupaya untuk meningkatkan atas kekurangan 
tersebut sebagai upaya untuk meningkatkan kearah yang lebih baik.

Berdasarkan uraian diatas maka dapat dikatakan bahwa kinerja guru adalah prestasi yang dicapai oleh seorang guru dalam mengelola dan melaksanakan pendidikan dan pengajaran.

\section{Kesimpulan}

1. Tingkat pendidikan guru Sekolah Menengah Pertama Negeri (SMPN) 3 Baba Kecamatan Cendana Kabupaten Enrekang memiliki tingkat pendidikan yang cukup memadai dalam hal ini dapat menunjang pekerjaan sehari-hari. Hal ini membuktikan bahwa guru Sekolah Menengah Pertama Negeri (SMPN) 3 Baba Kecamatan Cendana Kabupaten Enrekang 100 persen memiliki tingkat pendidikan sarjana (S1) dalam hal ini dapat menunjang pekerjaan sehari-hari.

2. Pengalaman kerja guru Sekolah Menengah Pertama Negeri (SMPN) 3 Baba Kecamatan Cendana Kabupaten Enrekang cukup matang, hal ini dilihat dari lamanya mereka bekerja(rata-rata 15 tahun) atau mengajar.

3. Kinerja guru Sekolah Menengah Pertama Negeri (SMPN) 3 Baba Kecamatan Cendana Kabupaten Enrekang berada pada kategori sangat tinggi.

4. Terdapat pengaruh antara tingkat pendidikan, dan pengalaman kerja guru terhadap kinerja guru Sekolah Menengah Pertama Negeri (SMPN) 3 Baba Kecamatan Cendana Kabupaten Enrekang.

\section{Saran}

Berdasarkan dari hasil penelitian dan kesimpulan yang telah diuraikan sebelumnya, maka dapat disarankan sebagai berikut:
1. Hendaknya kepala sekolah memperhatikan, meningkatkan tingkat pendidikan guru-guru yang ada sehingga kualitas pembelajaran terjamin.

2. Kepala sekolah memberikan kebebasan dalam mengembangkan pengalaman kerja dengan mengirim untuk lokakarya, penataran, serta workshop sehingga pengalaman kerja guru dapat memadai untuk melakukan tugas-tugas sehariharinya sebagai pengajar, dan pengayom masyarakat di lingkungannya.

3. Kinerja guru hendaknya didorong lebih baik lagi, sehingga nantinya dapat memenuhi target visi dan misi Sekolah Menengah Pertama Negeri (SMPN) 3 Baba Kecamatan Cendana Kabupaten Enrekang sekolah.

4. Guru dan kepala sekolah senantiasa meningkatkan kerjasama yang lebih baik lagi, sehingga dapat meningkatkan kualitas pengajaran yang lebih baik. Apabila tingkat pendidikan guru dengan pengalaman kerja guru baik, maka kinerja guru Sekolah Menengah Pertama Negeri (SMPN) 3 Baba Kecamatan Cendana Kabupaten Enrekang juga akan lebih baik pula dalam melaksanan tugas selanjutnya.

\section{DAFTAR PUSTAKA}

Arismunandar. 1997. Hubungan Karakteristik Individu dan Karakteristik Lingkungan Dengan Stres Kerja Guru di Sulawesi Selatan. Disertasi Tidak Dipublikasikan. Program Pasca Sarjana IKIP Malang.

Arismunandar, 2005. Manajemen Pendidikan Peluang dan 
Tantangan. Makassar: Badan Penerbit Universitas Negeri Makassar.

Bernadin, H. John \& Russel, Joyce E. A. 1993. Human Resources Management. Mc Graw Hill, Inc. : Singapore.

Byars, L.L. \& L.W. Rue. 1984. Human Resources \& Personnel Management.

Richard D. Irwin, Inc.: Homewood Illinois.

Djojonegoro, W. 1993. "Pidato Pengarahan Mendikbud RI". Dalam Raker LPTK Se Indonesia. 8-9 Nopember di Jakarta.

Echols, John M. \& Shadily, Hassan. 1975. Kamus Inggris-Indonesia. PT. Gramedia: Jakarta.

Fayol, H. 1945. General and Industrial Management. New York: Pitman Publishing Cooperation.

Fisher, D., 1990. The Assessment and Change of Classroom and School Enveriromment. Launceston: Tasmanian State Institute of Technology.

Fortunato, R. T., \& Waddell, D. G. 1981. Personnel Administration in Higher Education. First Edition. London: Jossy-Bass, Publishers, Inc.

Good, Carter V. 1959. Dictionary of Education. McGraw-Hill Book Company: New York.

Harris, B.M., et. Al. 2001. Personnel Administration inEducational. Boston: Allyn
Kartono, K., 1998. Pemimpin dan Kepemimpinan: Apakah Pemimpin Abnormal itu? Jakarta: PT. Raja Grafindo Persada.

Mantja, W., 2002. Manajemen Pendidikan dan Supervisi Pengajaran. Malang: Wineka Media.

Mulyasa, E. 2004. Menjadi Kepala Sekolah Profesional. Bandung: PT Remaja Rosdakarya.

Nawawi, H. 2005. Manajemen Strategik (Organisasi non Profit Bidang Pemeritahan dengan ilustrasi di bidang pendidikan. Yokyakarta: Gajah Mada University Press.

Owens, R. G. 1991. Organizational Behavior in Educational. Englewood Cliffs, New Jersey: Prentice-Hall, Inc.

Pidarta, M. 1992. Manajemen Pendidikan Indonesia. Jakarta: Bina Aksara.

Robbins, S.P. 1983. Essentials of Organizational Bahavior. Englewood Cliffs, New Jersey: Prentice-Hall, Inc.

Rusdinal, 2006. Pengembangan Organisasi dengan Pendekatan Manajemen Berbasis Sekolah (Studi multisitus pada tiga Sekolah Dasar di Kota Cendekia) Malang. Disertasi tidak dipublikasikan. PPS Universitas Negeri Malang.

Sagala, S., 2002. Administrasi Pendidikan Kontemporer. Bandung: CVAlfabeta. 
Sonhadji, K.H. 2007. Pokok-pokok Pikiran tentang Pengembangan Kompetensi Mengajar di Perguruan Tinggi. Jakarta: Universitas Terbuka.

Steers, R. M., Ungson, G.R., \& Mowday, R.T. 1986. Managing Effetiv Organization. Boston: Allyn and Bacon.

Sugiyono. 2001. Metode Penelitian Adninistrasi. Bandung: CVAlfabeta.

Syarifuddin. 2007. Hubungan Antara Strategi Manajemen Komplik organisasi oleh Kepala Sekolah, Iklim Sekolah, Insentif Guru, dan Motivasi Berprestasi Guru dengan Kinerja Guru SMK Negeri Di Sulawesi Selatan. Disertasi tidak dipublikasikan. PPS Universitas Negeri Malang.

Tilaar, H.A.R. 2002. Membenahi Pendidikan Nasional. Jakarta: PT Rineka Cipta.

Tiro, M.A. 1999. Dasar-Dasar Statistik. Makassar: Badan Penerbit UNM.

"Undang-undang Republik Indonesia Nomor 32 Tahun 2004 tentang Pemerintahan Daerah".

Winardi, J. 2004. Manajemen Perilaku Organisasi. Jakarta: Prenada Media. 